\title{
Network based meta-analysis prediction of microenvironmental relays involved in stemness of human embryonic stem cells
}

Background. Human embryonic stem cells (hESCs) are pluripotent cells derived from the inner cell mass of in vitro fertilised blastocysts, which can either be maintained in an undifferentiated state or committed into lineages under determined culture conditions. These cells offer great potential for regenerative medicine, but at present, little is known about the mechanisms that regulate hESC stemness; in particular, the role of cell-cell and cellextracellular matrix interactions remain relatively unexplored. Methods and results. In this study we have performed an in silico analysis of cell-microenvironment interactions to identify novel proteins that may be responsible for the maintenance of hESC stemness. A hESC transcriptome of 8,934 mRNAs was assembled using a meta-analysis approach combining the analysis of microarrays and the use of databases for annotation. The STRING database was utilised to construct a protein-protein interaction network focused on extracellular and transcription factor components contained within the assembled transcriptome. This interactome was structurally studied and filtered to identify a short list of 92 candidate proteins, which may regulate hESC stemness. Conclusion. We hypothesise that this list of proteins, either connecting extracellular components with transcriptional networks, or with hub or bottleneck properties, may contain proteins likely to be involved in determining stemness. 
1 Authors: Virginie Mournetas ${ }^{1,2}$, Quentin M. Nunes ${ }^{2,3}$, Patricia A. Murray ${ }^{1}$, Christopher M.

2 Sanderson $^{1}$, David G. Fernig ${ }^{2}$

3 Affiliations: ${ }^{1}$ Department of Cellular and Molecular Physiology, Institute of Translational

4 Medicine, ${ }^{2}$ Department of Biochemistry, Institute of Integrative Biology, ${ }^{3}$ NIHR Liverpool

5 Pancreas Biomedical Research Unit, Institute of Translational Medicine, University of Liverpool,

6 L697ZB Liverpool, United Kingdom 


\section{Introduction}

8 Human embryonic stem cells (hESCs) are pluripotent cells present in the inner cell mass of the

9 blastocyst (Pera et al. 2000). They give rise in vivo to the three germ layers (ectoderm, endoderm

10 and mesoderm), and, therefore, have the ability to generate all tissues within the body. These

11 cells can also be derived in vitro (Thomson et al. 1998), maintaining an ability to either self-

12 renew or differentiate (Keller 2005). Human ESCs are a fundamental tool for understanding

13 human embryonic development and constituent mechanisms of differentiation (Keller 2005).

14 Moreover, they represent a potentially powerful tool in drug screening (Jensen et al. 2009) and

15 regenerative medicine (Aznar \& Gomez 2012; Keller 2005; Wobus \& Boheler 2005). However,

16 in order to mobilise the potential of hESCs, it is necessary to understand the molecular

17 determinants of self-renewal and differentiation.

18 The core transcriptional network regulating pluripotency (Babaie et al. 2007; Boyer et al. 2005;

19 Chavez et al. 2009; Marson et al. 2008; Rodda et al. 2005), is composed of three transcription

20 factors: octamer-binding protein 4 (OCT4) (Hay et al. 2004), sex determining region Y-box 2

21 (SOX2) (ong et al. 2008) and NANOG (yslop et al. 2005; Zaehres et al. 2005). Interestingly,

22 although these transcription factors clearly drive pluripotency (Li et al. 2009; Takahashi et al.

23 2007), their expression is not restricted to hESCs (Atlasi et al. 2008; Leis et al. 2012; Liedtke et

24 al. 2007; Pierantozzi et al. 2011; Zangrossi et al. 2007). Thus, stemness must in part depend on

25 other hESC specific characteristics, such as the context of expression of these three transcription

26 factors. Protein-protein interaction networks may provide a valuable insight into this hESC

27 specific context (Boyer et al. 2005; Muller et al. 2008). Proteins of the cell microenvironment

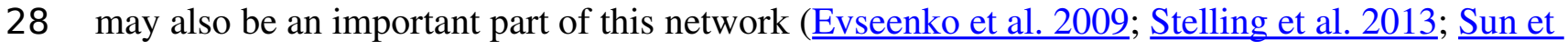

29 al. 2012), since this is the niche where cell-cell and cell-extracellular matrix (ECM) interactions 
30 occur, allowing selective cell communication. Indeed, it was through the addition of ECM

31 proteins and growth factors that xeno-free culture conditions for hESCs were defined

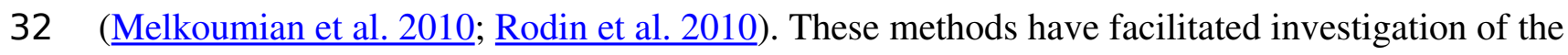

33 roles that extracellular molecules, such as heparan sulfate (HS) (Stelling et al. 2013), fibroblast

34 growth factor (FGF)-2 (Eiselleova et al. 2009; $\underline{\text { Greber et al. 2010) }}$ and activin A (Xiao et al.

35 2006) play in hESC self-renewal and differentiation. However, such factors have not always been

36 linked to specific transcriptional networks and many of the defined medium formulations do not

37 completely sustain pluripotency (Baxter et al. 2009; Ludwig et al. 2006). Therefore, other factors

38 involved in the maintenance of stemness must be missing. One key factor could be a wider link

39 between ECM interactions and transcriptional networks, thereby establishing important relay

40 mechanisms between endogenous and exogenous stemness regulators.

41 Data from large-scale transcriptomic and proteomic studies (Koh et al. 2012) facilitate the

42 construction of large biological networks in which nodes and edges represent molecules and

43 interactions respectively. Studying the topological properties of these networks may enable the

44 elaboration of novel hypotheses. For instance, it has been shown that hubs, which are highly

45 connected nodes within a network, are more likely to be important proteins in a protein-protein

46 interaction network (Jeong et al. 2001), as well as bottlenecks, which are nodes with a high

47 betweenness centrality, meaning many shortest paths within the network pass through them ( $\underline{\mathrm{Yu}}$

48 et al. 2007).

49 To gain a more global insight into the potential contribution of the cell-microenvironment to

50 stemness, we employed an in silico systems-level approach where a meta-analysis of dozens of

51 microarrays was performed to establish a stringent yet more representative hESC transcriptome.

52 Transcripts of transcriptional and extracellular proteins were used to build a putative interactome 
53 or protein-protein interaction network. The organisation of this network was then analysed to

54 identify extracellular proteins with hub or bottleneck properties, which may be involved in

55 determining stemness, as well as proteins connecting the extracellular factors to transcription. 


\section{Materials and methods}

\section{Establishing hESC and hESC-derived transcriptomes}

58 The microarray datasets used to establish a high coverage hESC transcriptome were raw data

59 (.CEL image files) of single channel Human Genome U133 Plus 2.0 Affymetrix microarrays

60 downloaded from the ArrayExpress public database (Parkinson et al. 2007). Probe intensity

61 extraction and normalisation procedures were performed with BRB-ArrayTools 4.3 .0 beta 1

62 (Simon et al. 2007) using default median array values (selected by BRB-ArrayTools 4.3.0 beta 1)

63 as reference. The minimum required fold change was 1.5 . If less than $20 \%$ of the expression

64 values met this value, the gene was excluded. Each individual dataset was first analysed using the

65 three available algorithms: Robust Multi-array Analysis (RMA) (Irizarry et al. 2003), GC-RMA

66 (Wu et al. 2004) and Micro Array Suite 5.0 (MAS5.0) (Hubbell et al. 2002). The three lists of

67 expressed genes were either combined to create a total list containing all expressed genes, or

68 compared to create an intersection list containing only overlapping genes. For the hESC datasets,

69 when the intersection list contained at least $50 \%$ of the genes of the total list, the dataset was used

70 to perform a meta-analysis to establish the hESC transcriptome. Thus, all hESC datasets

71 matching this criterion were grouped to be analysed together and generate the final intersection

72 list used as the hESC transcriptome for further analysis (Fig. 1). For the hESC-derived cell

73 datasets, if the intersection list contained at least $50 \%$ of the genes of the total list, the full

74 transcriptome (fibroblasts and endothelial cells) was used for transcriptomic comparisons;

75 otherwise the datasets were combined to build the final intersection list and form the hESC-

76 derived cell transcriptome, which was used for transcriptomic comparisons (Fig. 1). The

77 identifiers were EntrezGene IDs and Official Gene Symbol identifiers. The identifier conversion 
78 was done with the database for annotation, visualization and integrated discovery (DAVID) 6.7

79 (Huang da et al. 2009a; Huang da et al. 2009b).

80 Selection of extracellular and transcription related sub-transcriptomes

81 The extracellular (EC) and the transcription factor related (TF) components of the transcriptomes

82 were extracted using the Gene Ontology (GO) database (Ashburner et al. 2000). The terms used

83 were: GO:0005576 (extracellular region) and GO:0009986 (cell surface) for the EC component;

84 GO:0005667 (transcription factor complex), GO:0008134 (transcription factor binding),

85 GO:0000988 (protein binding transcription factor activity) and GO:0001071 (nucleic acid

86 binding transcription factor activity) for the TF component. Genes involved in biological

87 processes (e.g. cell cycle (GO:0007049), cell adhesion (GO:0007155), cell communication

88 (GO:0007154), cell junction (GO:0030054) and cytoskeleton organization (GO:0007010)) were

89 also highlighted.

90 By using a published list of HS binding proteins (Ori et al. 2011), the EC component was divided

91 into two distinct groups: genes coding for HS binding proteins and those coding for non-HS

92 binding proteins.

93 The hESC transcriptome was compared with the three different hESC-derived cell transcriptomes

94 to establish which mRNAs were only expressed in hESC (the specific part) and which ones were

95 expressed in all analysed transcriptomes (the common part).

\section{Construction and analysis of putative interactomes}

97 Putative interactomes were built with the Search Tool for the Retrieval of Interacting

98 Genes/Proteins (STRING) 9.0 database (Szklarczyk et al. 2011) using interaction data from

99 experimental/biochemical experiments and association in curated databases only, which excludes 
100 interaction predictions by neighbourhood in the genome, gene fusions, co-occurrence across

101 genomes, co-expression and text-mining (co-mentioned in PubMed abstracts). A stringent

102 interaction confidence of 0.7 was imposed, to ensure a higher probability that the predicted links

103 exist (Szklarczyk et al. 2011).

104 Analysis of network structure

105 Cytoscape 2.8.0 software ( $\underline{\text { Shannon et al. 2003) }}$ ) and associated plug-ins were used to visualise

106 and analyse protein-protein interaction networks. Randomised networks were created by the

107 RandomNetworks v1.0 plug-in from the real protein-protein interaction networks. Therefore,

108 each random network had the same number of nodes $\mathrm{N}$ and edges $\mathrm{L}$ as its corresponding real

109 network. Network topological parameters, such as connected components, average degree $<\mathrm{k}>$,

110 degree distribution $\mathrm{P}(\mathrm{k})$, average clustering coefficient $<\mathrm{C}>$, clustering coefficient distribution

$111 \mathrm{C}(\mathrm{k})$ and characteristic path length $<\mathrm{l}>$, were computed with the NetworkAnalyser plug-in.

112 Statistical analysis was performed using IBM SPSS Statistics 21 software.

\section{Enrichments analysis of interactome components}

114 Kyoto Encyclopedia of Genes and Genomes (KEGG) (Kanehisa \& Goto 2000) pathway and GO

115 Biological Processes term enrichments were processed using DAVID 6.7 (Huang da et al. 2009a;

116 Huang da et al. 2009b) for the analysis of transcriptome subsets. Terms were recorded when the

117 EASE score was $\leq 0.1$ and considered significantly enriched when the false discovery rate was $\leq$

118 0.05. Enrichment was calculated through two different ways: the ratio of the ratio of proteins

119 belonging to the term in the analysed list and the ratio of proteins belonging to the term in Homo

120 sapiens, or hESCs. 


\section{Selection of candidate proteins}

122 Proteins with a degree $\mathrm{k}$ in the top $20 \%$ were considered as hubs, while proteins with a

123 betweenness in the top 20\% were considered as bottlenecks (Yu et al. 2007). The EC/TF and

124 specific/common interfaces were established from the hESC sub-interactome, constructed with

125 STRING data (edge confidence of 0.7) and containing EC and TF components only. To be part of

126 the EC/TF interface network, an EC node had to be connected to a least one TF node and vice-

127 versa. Similarly, to be part of the specific/common interface, a specific node had to be connected

128 to a least one common node and vice-versa. In this complete (ALL_EC+TF) list of candidate

129 proteins composed of the two interfaces, hubs and bottlenecks, only the EC nodes from the

130 specific and common parts were kept to establish the final $\left(\mathrm{C}+\mathrm{S} \_\mathrm{EC}\right)$ short list of candidate

131 proteins (Fig. 2). The KEGG pathway and GO Biological Processes term enrichments were

132 processed as previously. Statistical analysis was performed using IBM SPSS Statistics 21

133 software and presented as mean \pm SEM. 


\section{Results}

\section{The hESC transcriptome}

136 To discover new regulators of hESC pluripotency, $24 \mathrm{hESC}$ microarrays were analysed from four

137 different datasets (Table 1). A total of 8,934 genes were found to be expressed, which constitute

138 the high coverage hESC transcriptome (Table S1). To establish hESC specific expression

139 profiles, three different early hESC-derived cell transcriptomes were extracted from analogous

140 fibroblast (5,086 mRNAs), endothelial cells (5,522 mRNAs) or mixed hESC-derived cells

141 (10,730 mRNAs, Table 1 and Table S1).

142 The mRNAs specifically expressed by the hESCs (1,010 mRNAs) and those common to hESCs

143 and hESC-derived cells (1,933 mRNAs) were identified by comparing the hESC trancriptome

144 with the hESC-derived trancriptomes (Fig. 3A). Gene Ontology (GO) annotation database

145 (Ashburner et al. 2000) was then used to identify the hESC transcription factor (TF) related (721

146 mRNAs) and extracellular (EC) transcripts. In this last set of mRNAs, a distinction between

147 transcripts coding for HS binding proteins (191 mRNAs) and non-binding proteins (576 mRNAs,

148 Fig. 3B and Table S1) was enabled by a published list of HS binding proteins (Ori et al. 2011).

149 Transcriptome analysis showed that genes known to be involved in stemness were represented in

150 this hESC transcriptome, such as POU class 5 homeobox 1 (POU5F1, which encodes OCT4

151 protein) (Nichols et al. 1998) and SOX2 (Avilion et al. 2003). As expected, some of these were in

152 the hESC specific sub-set, such as the telomerase reverse transcriptase (TERT) (Yang et al. 2008)

153 and growth differentiation factor 3 (GDF3) (Levine \& Brivanlou 2006) (Table 2A). Interestingly,

154 NANOG (Chambers et al. 2003) was not present here. Some germ layer markers were also found 
155 in the hESC transcriptome, but they were never specific (Table 2B). Lastly, many common

156 additions to cell culture medium, which have been observed to facilitate hESC growth in vitro,

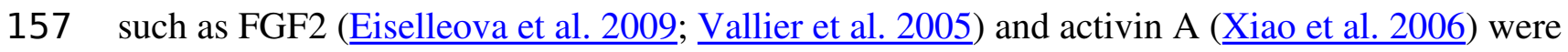

158 also present (Table 2C).

\section{Putative extracellular/transcriptional interactomes}

160 As the aim of this study was to learn more about the potential importance of functional links

161 between cell/cell-matrix interactions and transcription, putative protein-protein interaction

162 networks containing only transcriptional and extracellular components (EC+TF) were established

163 by means of the STRING database (Szklarczyk et al. 2011) using transcriptional expression data

164 as a proxy for protein expression profiles. Two interactomes were built: one (called ALL)

165 containing all identified EC+TF proteins, composed of 702 nodes and 3,201 edges (Data S1A),

166 and one (called $\mathrm{C}+\mathrm{S}$ ) containing only those transcripts/proteins that were either specific to hESCs

167 or common to hESCs and hESC-derived cells, comprising 209 nodes and 371 edges (Data S1B).

168 The average clustering coefficient $<\mathrm{C}>$ (indicating the network cohesiveness) was closer to zero

169 for all randomised networks compared to both ALL and C+S interactomes, implying a

170 significantly higher occurrence of clusters in these selected networks (Fig. 4A).

171 As observed in previous protein-protein interaction network studies (Albert et al. 2000; $\underline{\text { Jeong et }}$

172 al. 2001), both selected networks (ALL and C+S) and randomised networks exhibit a scale-free

173 structure, where the degree distribution $\mathrm{P}(\mathrm{k})$ follows a power-law $P(k) k^{-\gamma}$, involving the

174 presence of hubs (Fig. 4B and Table S2), and the clustering coefficient distribution $\mathrm{C}(\mathrm{k})$ is

175 independent of $\mathrm{k}$ meaning there is no inherent presence of modules unlike hierarchical networks, 
176 even if there was a tendency to be hierarchical ( $C(k) k^{-\beta}$ ) compared to the randomised

177 versions (Fig. 4C).

178 These results demonstrate that the EC+TF putative protein-protein interaction networks were

179 suitable for further analysis.

\section{Enrichment analysis}

181 GO Biological Processes term and KEGG pathway enrichments were used to determine if the

182 EC+TF putative interactomes contained significantly enriched sub-sets of proteins. As expected,

183 terms related to EC (extracellular matrix organization), and TF (transcription, DNA templated)

184 appeared. More interestingly, terms relating to development (embryonic development) and

185 pathways already known to be involved in hESC stemness maintenance (transforming growth

186 factor (TGF)- $\beta$ ( $\underline{\text { James et al. 2005) }}$ ) or wingless-type MMTV integration site family (Wnt) ( $\underline{\text { Sato }}$

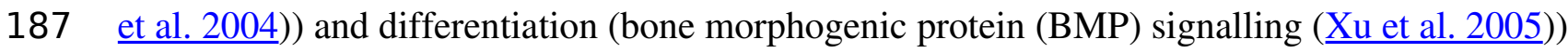

188 were also identified. KEGG Pathways in cancer as well as GO terms of cell differentiation, cell

189 adhesion, cell communication and cell proliferation were represented too (Fig. 5 and Table S3A).

190 Fewer terms were found to be significantly enriched when only the common and specific parts

191 (from ALL to C+S) were analysed. However, when they were found significant, the vast majority

192 was more enriched, except the terms related to TF (Table S3A). Nuclear-transcribed mRNA

193 catabolic process (representing 56\% of ALL and 48\% of C+S) and multicellular organismal

194 development (representing 47\% of ALL and 54\% of C+S) were the most represented non-related 195 terms (Table S3A). 
196 Interestingly, regulation of cellular component movement was well enriched with fold changes in

197 ALL of 5.8 (Homo sapiens as background)/4.6 (hESC as background) and in $\mathrm{C}+\mathrm{S}$ of 9.4 (Homo

198 sapiens as background)/7.4 (hESC as background). $28 \% / 51 \%$ of the proteins belonging to this

199 term in Homo sapiens/hESC were represented in ALL and 17\%/31\% in C+S (Table S3A).

200 These data show that the EC+TF putative interactomes, both ALL and C+S, still contained the

201 sub-sets of proteins involved in development, cell differentiation, cell adhesion and cell

202 communication.

203 Novel proteins potentially associated with stemness

204 The final list of potential stemness proteins was established from ALL, the EC+TF putative

205 protein-protein interaction network. This list (called ALL_EC+TF) was composed of nodes with

206 hub or bottleneck features, as well as nodes within the specific/common and EC/TF interfaces

207 (Fig. 2). Hubs are thought to be functionally important due to their high number of interactions,

208 while bottlenecks form links between different processes. 58\% of the bottlenecks in the ALL

209 network were also hubs. The specific/common interface reflects the links between the more

210 general cell functions and those specific to hESCs. The EC/TF interface represents points of

211 communication between the genome and the cell's environment, including other cells. The

212 ALL_EC+TF contained 387 candidates (49\% EC and 55\% TF) with 29 specific (8\%) and 126

213 common (33\%) nodes. The key transcription factors OCT4 and SOX2 were present as hubs and

214 part of the EC/TF interface (Table S4A).

215 Considering GO set (TF, EC) enrichment with regards to proteins belonging to common or

216 specific parts of the transcriptome, the specific sub-set was enriched in non-HS binding EC

217 proteins (1.7-fold change), whereas the common sub-set was enriched in HS binding proteins 
218 (1.6-fold change) (Fig. 6A). In addition the common sub-set was found to be enriched in both

219 hubs (1.3-fold change) and bottlenecks (1.6-fold change) (Fig. 6B). Finally, hubs were enriched

220 in TF (1.4-fold change) and bottlenecks in HS binding proteins (1.3-fold change, Fig. 6B).

221 To assess the validity of the candidate prediction, a random ALL_EC+TF list was established the

222 same way using a randomised version of the EC+TF putative interactome (Table S4B). The hub

223 sub-set was identical in both real and random versions of the candidate list due to the way the

224 randomised network was generated. However, the bottleneck sub-set in the real list had proteins

225 with significantly higher betweenness centrality $(7,456 \pm 835$, paired sample test, $n=134$, $p$ -

226 value $<0.001)$ than the one in the random list $(0.0108 \pm 0.0005)$. Moreover, the random list with

227581 proteins retained $83 \%$ of the original EC+TF putative interactome against $55 \%$ for the real

228 list. The comparison between the real list of candidates and its random version showed that the

229 filtering process was meaningful.

230 Three shortened lists were generated from ALL_EC+TF list to decrease the number of candidates

231 by either keeping only EC proteins (ALL_EC, 188 proteins, Table S4C) or/and C+S proteins

232 (C+S_EC+TF, 155 proteins, Table S4D and C+S_EC, 92 proteins, Table S4E) as described in

233 Fig. 2. 59\% of the common proteins in the longest ALL_EC+TF list and 62\% of the specific ones

234 were conserved in the shortest C+S_EC list. Similarly, 9\% of the hubs and 20\% of the

235 bottlenecks were kept.

236 To determine if each list and each sub-set (hubs, bottlenecks and interfaces, as well as specific,

237 common and other proteins from the complete (ALL_EC+TF) to the shortest (C+S_EC) list) still

238 contained proteins potentially involved in stemness maintenance, we undertook further GO

239 Biological Processes term and KEGG pathway enrichments (Table S3B-I). Only the sub-set 


\section{PeerJ Reviewing Manuscript}

240 containing the hESC-specific proteins was found without any significant enrichment regarding

241 the analysed terms and pathways (Table S3C). However, the most represented term in both

242 specific sub-sets from the ALL_EC+TF and ALL_EC, as well as in the four full lists and in all

243 other sub-sets, was multicellular organismal development (Table S3B-I).

244 Again, terms and pathways related to TF appeared in ALL_EC+TF and C+S_EC+TF lists, as

245 well as in all the other sub-sets of these two lists (Table S3B,D-I). These TF terms and pathways

246 were logically lost in the ALL_EC and C+S_EC lists and sub-sets.

247 GO terms related to cell differentiation, cell adhesion, cell communication, cell movement or cell

248 proliferation, and KEGG pathways of cancer were still significantly enriched in the four lists and

249 in the vast majority of the analysed sub-sets (Table S3B,D-I).

250 These data demonstrate that the four lists of candidates, as well as each sub-set of proteins (hubs,

251 bottlenecks, specific/common and EC/TF interfaces) incorporated proteins involved in

252 development and cell communication. Focusing on the EC proteins that were either specific to

253 hESCs or common to hESCs and hESC-derived cells allowed us to reduce the number of

254 candidates to 92 proteins (Table 3 and Table S4E), while insuring that proteins potentially

255 involved in stemness maintenance were retained. Among these proteins, some are already known

256 to be required for maintenance of hESC stemness, either directly, such as NODAL (James et al.

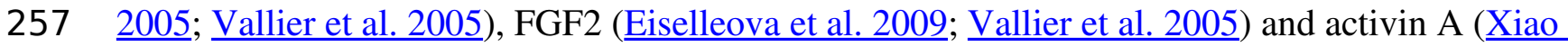

258 et al. 2006), or indirectly through signalling pathways such as TGF- $\beta$ (James et al. 2005) or Wnt

259 (Sato et al. 2004). Other proteins are also known to play a role in mouse ESC pluripotency, but

260 not yet in hESC, such as the transcription factor 3 (TCF3) (Cole et al. 2008). However, for the 
261 majority of candidates, including titin, nothing is known yet about their functions in the context 262 of hESCs. 


\section{Discussion}

264 We provide a novel picture of the hESC transcriptome built from a meta-analysis and allowing

265 the in silico analysis of a putative hESC protein-protein interaction network. This systems-level

266 approach has been used to identify proteins potentially involved in the maintenance of stemness.

267 Transcriptomic data provide the most comprehensive insight into variations in cell type or

268 condition specific gene expression profiles. Therefore, data from multiple microarray studies

269 were chosen to generate putative interactomes due to the lack of corresponding comprehensive

270 proteomic profiles. Even if mRNA and protein levels have been suggested to correlate weakly,

271 this correlation may be stronger than anticipated, though this depends on the techniques used to

272 measure mRNA (Jingyi et al. 2014; Pascal et al. 2008; $\underline{\text { Schwanhausser et al. 2011; }}$

273 Schwanhäusser et al. 2013). Thus, the present study provides a predictive qualitative insight into

274 sub-networks of proteins, which may mediate or maintain human stem cell pluripotency.

275 The decision to selectively include genes only found by three different algorithms allowed a

276 reduction in the number of false positives in the whole transcriptome, but probably amplified the

277 number of false negatives, which may explain the absence of NANOG. Regarding the

278 specific/common distinction, this pipeline permitted confidence about the common mRNA sub-

279 set, whereas it likely increased the false positive rate in the specific mRNA sub-set, which is still

280 half the common one. However, the use of transcriptomic data from different hESC lines cultured

281 under different conditions highlighted the core transcriptome of these cells.

282 Not all mRNAs were represented in the putative protein-protein interaction network, probably

283 because coverage of human protein-protein interactions in all databases, including STRING,

284 remains incomplete (De Las Rivas \& Fontanillo 2010). High edge stringency limits imposed in 


\section{PeerJ Reviewing Manuscript}

285 this study should minimise inclusion of false positive interactions (De Las Rivas \& Fontanillo

286 2010), thereby increasing confidence in the relevance and utility of predicted networks.

287 The scale free nature of the EC+TF putative interactomes, mean that they should exhibit a high

288 error tolerance thanks to redundancy and a high attack vulnerability, due to the presence of hubs

289 (Albert et al. 2000).

290 Even incomplete interactomes are very complex structures. In order to focus on the likely most

291 important proteins within this interactome, four selection criteria were applied, the first being the

292 selection of hESC hubs. These proteins constitute a small, but often essential part of the

293 interactome (Awan et al. 2007). For example, deletion of just one hub in yeast is often lethal

294 (Jeong et al. 2001). The second was the selection of bottlenecks, which link processes and so

295 permit cross-talk. The third and the fourth criteria involved were that proteins had to be in the

296 specific/common or EC/TF interfaces. These interfaces are posited to be important, as they reflect

297 communication links between the nucleus and the extracellular matrix, and between the specific

298 and common proteins, which ultimately make hESCs different from other cell types.

299 Interestingly, the GO term related to cell motility regulation was strongly represented in the

300 candidate lists. Cell movement is a key component of morphogenesis. It is usually accomplished

301 by three steps (protrusion, adhesion and de-adhesion) where cytoskeleton and ECM are involved

302 (Ananthakrishnan \& Ehrlicher 2007). This may be significant as recent data indicates that cell

303 motion may be an intrinsic feature of hESCs (Li et al. 2010).

304 Regulation of cell proliferation also appeared in our analysis of candidate lists. This may be

305 significant, as cell proliferation is a key property of hESCs, since these cells are able to

306 proliferate almost indefinitely in vitro (Miura et al. 2004). This capability is sustained by the EC

307 part with growth factors (Activin A (Baxter et al. 2009) and FGF2 ( 


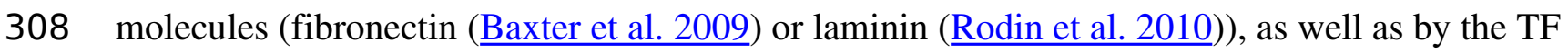

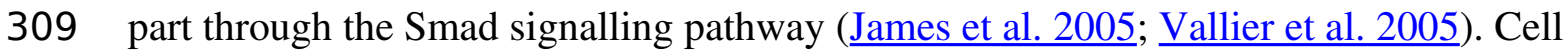

310 proliferation can also be linked to the significant enrichment of cancer pathways in hESCs.

311 Several links arise between cancer and hESCs, for example, the formation of teratomas as a test

312 to assess pluripotency.

\section{Conclusion}

314 Mechanisms involved in stemness are complex, multi-level and determined by the intrinsic cell

315 potential, cell/cell and cell/matrix interactions. The meta-analysis of transcriptomic data in this

316 study has allowed the construction of a hESC putative protein-protein interaction network from

317 which novel ECM proteins have been identified as potential stemness regulators.

318 Networks are a snapshot of a dynamic model (Assmus et al. 2006; Peltier \& Schaffer 2010).

319 Notions of attractors (or cell stable stationary states), landscapes formed with valleys (attractors)

320 and hills (barriers between attractors), and cell state transitions described by dynamic systems

321 theory will complete this systems biology approach and bring new hypotheses on hESC

322 behaviour (MacArthur et al. 2008; Macarthur et al. 2009; Peltier \& Schaffer 2010; $\underline{\text { Roeder \& }}$

323 Radtke 2009). 


\section{Acknowledgments}

325 All publications based on BRB-ArrayTools analyses will contain the acknowledgment: "Analyses

326 were performed using BRB-ArrayTools developed by Dr Richard Simon and BRB-ArrayTools

327 Development Team." 


\section{References}

329

330

331

332

333

334

335

336

337

338

339

340

341

342

343

344

345

346

347

348

349

350

351

352

353

354

355

356

357

358

359

360

361

362

363

364

365

366

367

368

369

370
Albert R, Jeong H, and Barabasi AL. 2000. Error and attack tolerance of complex networks. Nature 406:378-382.

Ananthakrishnan R, and Ehrlicher A. 2007. The forces behind cell movement. Int J Biol Sci 3:303-317.

Ashburner M, Ball CA, Blake JA, Botstein D, Butler H, Cherry JM, Davis AP, Dolinski K, Dwight SS, Eppig JT, Harris MA, Hill DP, Issel-Tarver L, Kasarskis A, Lewis S, Matese JC, Richardson JE, Ringwald M, Rubin GM, and Sherlock G. 2000. Gene ontology: tool for the unification of biology. The Gene Ontology Consortium. Nat Genet 25:25-29.

Assmus HE, Herwig R, Cho KH, and Wolkenhauer O. 2006. Dynamics of biological systems: role of systems biology in medical research. Expert Rev Mol Diagn 6:891-902.

Atlasi Y, Mowla SJ, Ziaee SA, Gokhale PJ, and Andrews PW. 2008. OCT4 spliced variants are differentially expressed in human pluripotent and nonpluripotent cells. Stem Cells 26:3068-3074.

Avilion AA, Nicolis SK, Pevny LH, Perez L, Vivian N, and Lovell-Badge R. 2003. Multipotent cell lineages in early mouse development depend on SOX2 function. Genes Dev 17:126140.

Awan A, Bari H, Yan F, Moksong S, and Yang... S. 2007. Regulatory network motifs and hotspots of cancer genes in a mammalian cellular signalling network. Regulatory network motifs and hotspots of cancer genes in a mammalian cellular signalling network.

Aznar J, and Gomez I. 2012. Possible clinical usefulness of embryonic stem cells. Rev Clin Esp 212:403-406.

Babaie Y, Herwig R, Greber B, Brink TC, Wruck W, Groth D, Lehrach H, Burdon T, and Adjaye J. 2007. Analysis of Oct4-dependent transcriptional networks regulating self-renewal and pluripotency in human embryonic stem cells. Stem Cells 25:500-510.

Baker DE, Harrison NJ, Maltby E, Smith K, Moore HD, Shaw PJ, Heath PR, Holden H, and Andrews PW. 2007. Adaptation to culture of human embryonic stem cells and oncogenesis in vivo. Nat Biotechnol 25:207-215.

Baxter MA, Camarasa MV, Bates N, Small F, Murray P, Edgar D, and Kimber SJ. 2009. Analysis of the distinct functions of growth factors and tissue culture substrates necessary for the long-term self-renewal of human embryonic stem cell lines. Stem Cell Res.

Boyer LA, Lee TI, Cole MF, Johnstone SE, Levine SS, Zucker JP, Guenther MG, Kumar RM, Murray HL, Jenner RG, Gifford DK, Melton DA, Jaenisch R, and Young RA. 2005. Core transcriptional regulatory circuitry in human embryonic stem cells. Cell 122:947-956.

Chambers I, Colby D, Robertson M, Nichols J, Lee S, Tweedie S, and Smith A. 2003. Functional expression cloning of Nanog, a pluripotency sustaining factor in embryonic stem cells. Cell 113:643-655.

Chavez L, Bais AS, Vingron M, Lehrach H, Adjaye J, and Herwig R. 2009. In silico identification of a core regulatory network of OCT4 in human embryonic stem cells using an integrated approach. BMC Genomics 10:314.

Cole MF, Johnstone SE, Newman JJ, Kagey MH, and Young RA. 2008. Tcf3 is an integral component of the core regulatory circuitry of embryonic stem cells. Genes Dev 22:746755 . 
371

372

373

374

375

376

377

378

379

380

381

382

383

384

385

386

387

388

389

390

391

392

393

394

395

396

397

398

399

400

401

402

403

404

405

406

407

408

409

410

411

412

413

414

415

De Las Rivas J, and Fontanillo C. 2010. Protein-protein interactions essentials: key concepts to building and analyzing interactome networks. PLoS Comput Biol 6:e1000807.

Eiselleova L, Matulka K, Kriz V, Kunova M, Schmidtova Z, Neradil J, Tichy B, Dvorakova D, Pospisilova S, Hampl A, and Dvorak P. 2009. A complex role for FGF-2 in self-renewal, survival, and adhesion of human embryonic stem cells. Stem Cells 27:1847-1857.

Evseenko D, Schenke-Layland K, Dravid G, Zhu Y, Hao QL, Scholes J, Wang XC, Maclellan WR, and Crooks GM. 2009. Identification of the critical extracellular matrix proteins that promote human embryonic stem cell assembly. Stem Cells Dev 18:919-928.

Evseenko D, Zhu Y, Schenke-Layland K, Kuo J, Latour B, Ge S, Scholes J, Dravid G, Li X, MacLellan WR, and Crooks GM. 2010. Mapping the first stages of mesoderm commitment during differentiation of human embryonic stem cells. Proceedings of the National Academy of Sciences of the United States of America 107:13742-13747.

Fong H, Hohenstein KA, and Donovan PJ. 2008. Regulation of self-renewal and pluripotency by Sox2 in human embryonic stem cells. Stem Cells 26:1931-1938.

Greber B, Wu G, Bernemann C, Joo JY, Han DW, Ko K, Tapia N, Sabour D, Sterneckert J, Tesar $\mathrm{P}$, and Scholer HR. 2010. Conserved and divergent roles of FGF signaling in mouse epiblast stem cells and human embryonic stem cells. Cell Stem Cell 6:215-226.

Hay DC, Sutherland L, Clark J, and Burdon T. 2004. Oct-4 knockdown induces similar patterns of endoderm and trophoblast differentiation markers in human and mouse embryonic stem cells. Stem Cells 22:225-235.

Hu K, Yu J, Suknuntha K, Tian S, Montgomery K, Choi KD, Stewart R, Thomson JA, and Slukvin, II. 2011. Efficient generation of transgene-free induced pluripotent stem cells from normal and neoplastic bone marrow and cord blood mononuclear cells. Blood 117:e109-119.

Huang da W, Sherman BT, and Lempicki RA. 2009a. Bioinformatics enrichment tools: paths toward the comprehensive functional analysis of large gene lists. Nucleic Acids Res 37:113.

Huang da W, Sherman BT, and Lempicki RA. 2009b. Systematic and integrative analysis of large gene lists using DAVID bioinformatics resources. Nat Protoc 4:44-57.

Hubbell E, Liu WM, and Mei R. 2002. Robust estimators for expression analysis. Bioinformatics 18:1585-1592.

Hyslop L, Stojkovic M, Armstrong L, Walter T, Stojkovic P, Przyborski S, Herbert M, Murdoch A, Strachan T, and Lako M. 2005. Downregulation of NANOG induces differentiation of human embryonic stem cells to extraembryonic lineages. Stem Cells 23:1035-1043.

Irizarry RA, Bolstad BM, Collin F, Cope LM, Hobbs B, and Speed TP. 2003. Summaries of Affymetrix GeneChip probe level data. Nucleic Acids Res 31:e15.

James D, Levine AJ, Besser D, and Hemmati-Brivanlou A. 2005. TGFbeta/activin/nodal signaling is necessary for the maintenance of pluripotency in human embryonic stem cells. Development 132:1273-1282.

Jensen J, Hyllner J, and Bjorquist P. 2009. Human embryonic stem cell technologies and drug discovery. J Cell Physiol 219:513-519.

Jeong H, Mason SP, Barabasi AL, and Oltvai ZN. 2001. Lethality and centrality in protein networks. Nature 411:41-42.

Jingyi JL, Peter JB, and Mark DB. 2014. System wide analyses have underestimated protein abundances and the importance of transcription in mammals. PeerJ 2.

PeerJ reviewing PDF | (v2014:06:2206:1:0:NEW 16 Sep 2014) 
422

423

424

425

426

427

428

429

430

431

432

433

434

435

436

437

438

439

440

441

442

443

444

445

446

447

448

449

450

451

452

453

454

455

456

457

458

459

Kanehisa M, and Goto S. 2000. KEGG: kyoto encyclopedia of genes and genomes. Nucleic Acids Res 28:27-30.

Keller G. 2005. Embryonic stem cell differentiation: emergence of a new era in biology and medicine. Genes Dev 19:1129-1155.

Koh GC, Porras P, Aranda B, Hermjakob H, and Orchard SE. 2012. Analyzing protein-protein interaction networks. J Proteome Res 11:2014-2031.

Leis O, Eguiara A, Lopez-Arribillaga E, Alberdi MJ, Hernandez-Garcia S, Elorriaga K, Pandiella A, Rezola R, and Martin AG. 2012. Sox2 expression in breast tumours and activation in breast cancer stem cells. Oncogene 31:1354-1365.

Levine AJ, and Brivanlou AH. 2006. GDF3, a BMP inhibitor, regulates cell fate in stem cells and early embryos. Development 133:209-216.

Li L, Wang BH, Wang S, Moalim-Nour L, Mohib K, Lohnes D, and Wang L. 2010. Individual cell movement, asymmetric colony expansion, rho-associated kinase, and E-cadherin impact the clonogenicity of human embryonic stem cells. Biophys J 98:2442-2451.

Li W, Wei W, Zhu S, Zhu J, Shi Y, Lin T, Hao E, Hayek A, Deng H, and Ding S. 2009. Generation of rat and human induced pluripotent stem cells by combining genetic reprogramming and chemical inhibitors. Cell Stem Cell 4:16-19.

Liedtke S, Enczmann J, Waclawczyk S, Wernet P, and Kogler G. 2007. Oct4 and its pseudogenes confuse stem cell research. Cell Stem Cell 1:364-366.

Lu SJ, Hipp JA, Feng Q, Hipp JD, Lanza R, and Atala A. 2007. GeneChip analysis of human embryonic stem cell differentiation into hemangioblasts: an in silico dissection of mixed phenotypes. Genome biology 8:R240.

Ludwig TE, Levenstein ME, Jones JM, Berggren WT, Mitchen ER, Frane JL, Crandall LJ, Daigh CA, Conard KR, Piekarczyk MS, Llanas RA, and Thomson JA. 2006. Derivation of human embryonic stem cells in defined conditions. Nat Biotechnol 24:185-187.

MacArthur BD, Ma'ayan A, and Lemischka IR. 2008. Toward stem cell systems biology: from molecules to networks and landscapes. Cold Spring Harb Symp Quant Biol 73:211-215.

Macarthur BD, Ma'ayan A, and Lemischka IR. 2009. Systems biology of stem cell fate and cellular reprogramming. Nat Rev Mol Cell Biol 10:672-681.

Marson A, Levine SS, Cole MF, Frampton GM, Brambrink T, Johnstone S, Guenther MG, Johnston WK, Wernig M, Newman J, Calabrese JM, Dennis LM, Volkert TL, Gupta S, Love J, Hannett N, Sharp PA, Bartel DP, Jaenisch R, and Young RA. 2008. Connecting microRNA genes to the core transcriptional regulatory circuitry of embryonic stem cells. Cell 134:521-533.

Melkoumian Z, Weber JL, Weber DM, Fadeev AG, Zhou Y, Dolley-Sonneville P, Yang J, Qiu L, Priest CA, Shogbon C, Martin AW, Nelson J, West P, Beltzer JP, Pal S, and Brandenberger R. 2010. Synthetic peptide-acrylate surfaces for long-term self-renewal and cardiomyocyte differentiation of human embryonic stem cells. Nat Biotechnol 28:606-610.

Miura T, Mattson MP, and Rao MS. 2004. Cellular lifespan and senescence signaling in embryonic stem cells. Aging Cell 3:333-343.

Muller FJ, Laurent LC, Kostka D, Ulitsky I, Williams R, Lu C, Park IH, Rao MS, Shamir R, Schwartz PH, Schmidt NO, and Loring JF. 2008. Regulatory networks define phenotypic classes of human stem cell lines. Nature 455:401-405.

PeerJ reviewing PDF | (v2014:06:2206:1:0:NEW 16 Sep 2014) 
460

461

462

463

464

465

466

467

468

469

470

471

472

473

474

475

476

477

478

479

480

481

482

483

484

485

486

487

488

489

490

491

492

493

494

495

496

497

498

499

500

501

502

503

504

Nichols J, Zevnik B, Anastassiadis K, Niwa H, Klewe-Nebenius D, Chambers I, Scholer H, and Smith A. 1998. Formation of pluripotent stem cells in the mammalian embryo depends on the POU transcription factor Oct4. Cell 95:379-391.

Ori A, Wilkinson MC, and Fernig DG. 2011. A systems biology approach for the investigation of the heparin/heparan sulfate interactome. J Biol Chem.

Park IH, Zhao R, West JA, Yabuuchi A, Huo H, Ince TA, Lerou PH, Lensch MW, and Daley GQ. 2008. Reprogramming of human somatic cells to pluripotency with defined factors. Nature 451:141-146.

Parkinson H, Kapushesky M, Shojatalab M, Abeygunawardena N, Coulson R, Farne A, Holloway E, Kolesnykov N, Lilja P, Lukk M, Mani R, Rayner T, Sharma A, William E, Sarkans U, and Brazma A. 2007. ArrayExpress--a public database of microarray experiments and gene expression profiles. Nucleic Acids Res 35:D747-750.

Pascal LE, True LD, Campbell DS, Deutsch EW, Risk M, Coleman IM, Eichner LJ, Nelson PS, and Liu AY. 2008. Correlation of mRNA and protein levels: cell type-specific gene expression of cluster designation antigens in the prostate. BMC Genomics 9:246.

Peltier J, and Schaffer DV. 2010. Systems biology approaches to understanding stem cell fate choice. IET Syst Biol 4:1-11.

Pera MF, Reubinoff B, and Trounson A. 2000. Human embryonic stem cells. J Cell Sci 113 ( Pt 1):5-10.

Pierantozzi E, Gava B, Manini I, Roviello F, Marotta G, Chiavarelli M, and Sorrentino V. 2011. Pluripotency regulators in human mesenchymal stem cells: expression of NANOG but not of OCT-4 and SOX-2. Stem Cells Dev 20:915-923.

Rodda DJ, Chew JL, Lim LH, Loh YH, Wang B, Ng HH, and Robson P. 2005. Transcriptional regulation of nanog by OCT4 and SOX2. J Biol Chem 280:24731-24737.

Rodin S, Domogatskaya A, Strom S, Hansson EM, Chien KR, Inzunza J, Hovatta O, and Tryggvason K. 2010. Long-term self-renewal of human pluripotent stem cells on human recombinant laminin-511. Nat Biotechnol 28:611-615.

Roeder I, and Radtke F. 2009. Stem cell biology meets systems biology. Development 136:35253530.

Sato N, Meijer L, Skaltsounis L, Greengard P, and Brivanlou AH. 2004. Maintenance of pluripotency in human and mouse embryonic stem cells through activation of Wnt signaling by a pharmacological GSK-3-specific inhibitor. Nat Med 10:55-63.

Schwanhausser B, Busse D, Li N, Dittmar G, Schuchhardt J, Wolf J, Chen W, and Selbach M. 2011. Global quantification of mammalian gene expression control. Nature 473:337-342.

Schwanhäusser B, Busse D, Li N, Dittmar G, Schuchhardt J, Wolf J, Chen W, and Selbach M. 2013. Corrigendum: Global quantification of mammalian gene expression control. Nature 495:126-127.

Shannon P, Markiel A, Ozier O, Baliga NS, Wang JT, Ramage D, Amin N, Schwikowski B, and Ideker T. 2003. Cytoscape: a software environment for integrated models of biomolecular interaction networks. Genome Res 13:2498-2504.

Si-Tayeb K, Noto FK, Nagaoka M, Li J, Battle MA, Duris C, North PE, Dalton S, and Duncan SA. 2010. Highly efficient generation of human hepatocyte-like cells from induced pluripotent stem cells. Hepatology 51:297-305.

Simon R, Lam A, Li MC, Ngan M, Menenzes S, and Zhao Y. 2007. Analysis of gene expression data using BRB-ArrayTools. Cancer Inform 3:11-17. 
505

506

507

508

509

510

511

512

513

514

515

516

517

518

519

520

521

522

523

524

525

526

527

528

529

530

531

532

533

534

535

536

537

538

539

540

541

542

543

544

545

546

547

Stelling MP, Lages YM, Tovar AM, Mourao PA, and Rehen SK. 2013. Matrix-bound heparan sulfate is essential for the growth and pluripotency of human embryonic stem cells. Glycobiology 23:337-345.

Sun Y, Villa-Diaz LG, Lam RH, Chen W, Krebsbach PH, and Fu J. 2012. Mechanics regulates fate decisions of human embryonic stem cells. PLoS One 7:e37178.

Szklarczyk D, Franceschini A, Kuhn M, Simonovic M, Roth A, Minguez P, Doerks T, Stark M, Muller J, Bork P, Jensen LJ, and von Mering C. 2011. The STRING database in 2011: functional interaction networks of proteins, globally integrated and scored. Nucleic Acids Res 39:D561-568.

Takahashi K, Tanabe K, Ohnuki M, Narita M, Ichisaka T, Tomoda K, and Yamanaka S. 2007. Induction of pluripotent stem cells from adult human fibroblasts by defined factors. Cell 131:861-872.

Thomson JA, Itskovitz-Eldor J, Shapiro SS, Waknitz MA, Swiergiel JJ, Marshall VS, and Jones JM. 1998. Embryonic stem cell lines derived from human blastocysts. Science 282:11451147.

Vallier L, Alexander M, and Pedersen RA. 2005. Activin/Nodal and FGF pathways cooperate to maintain pluripotency of human embryonic stem cells. J Cell Sci 118:4495-4509.

Wobus AM, and Boheler KR. 2005. Embryonic stem cells: prospects for developmental biology and cell therapy. Physiol Rev 85:635-678.

Wu Z, Irizarry R, Gentleman R, Murillo F, and Spencer F. 2004. A Model Based Background Adjustment for Oligonucleotide Expression Arrays. bepress.

Xiao L, Yuan X, and Sharkis SJ. 2006. Activin A maintains self-renewal and regulates fibroblast growth factor, Wnt, and bone morphogenic protein pathways in human embryonic stem cells. Stem Cells 24:1476-1486.

Xu RH, Peck RM, Li DS, Feng X, Ludwig T, and Thomson JA. 2005. Basic FGF and suppression of BMP signaling sustain undifferentiated proliferation of human ES cells. Nat Methods 2:185-190.

Yang C, Przyborski S, Cooke MJ, Zhang X, Stewart R, Anyfantis G, Atkinson SP, Saretzki G, Armstrong L, and Lako M. 2008. A key role for telomerase reverse transcriptase unit in modulating human embryonic stem cell proliferation, cell cycle dynamics, and in vitro differentiation. Stem Cells 26:850-863.

Yu H, Kim PM, Sprecher E, Trifonov V, and Gerstein M. 2007. The importance of bottlenecks in protein networks: correlation with gene essentiality and expression dynamics. PLoS Comput Biol 3:e59.

Yu J, Hu K, Smuga-Otto K, Tian S, Stewart R, Slukvin, II, and Thomson JA. 2009. Human induced pluripotent stem cells free of vector and transgene sequences. Science 324:797801.

Zaehres H, Lensch MW, Daheron L, Stewart SA, Itskovitz-Eldor J, and Daley GQ. 2005. Highefficiency RNA interference in human embryonic stem cells. Stem Cells 23:299-305.

Zangrossi S, Marabese M, Broggini M, Giordano R, D'Erasmo M, Montelatici E, Intini D, Neri A, Pesce M, Rebulla P, and Lazzari L. 2007. Oct-4 expression in adult human differentiated cells challenges its role as a pure stem cell marker. Stem Cells 25:16751680.

PeerJ reviewing PDF | (v2014:06:2206:1:0:NEW 16 Sep 2014) 


\section{Figure 1}

Flow chart of the microarray dataset analysis

This flow chat describes the microarray meta-analysis process ending by the transcriptomes establishment of hESC, endothelial cells, fibroblasts and mixed hESC-derived cells. 


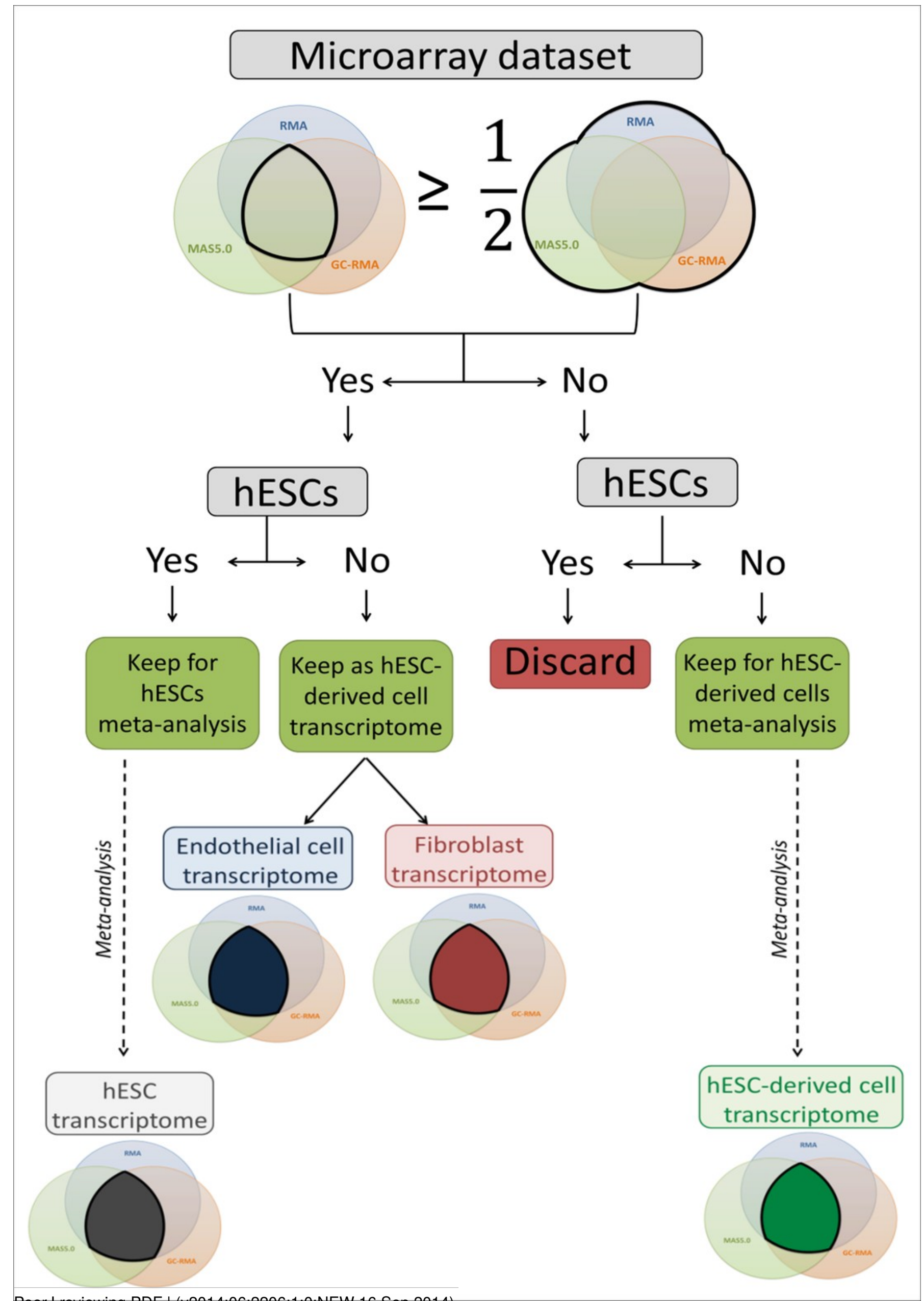




\section{Figure 2}

Establishment of the list of candidates, a flow chart

This flow chart describes the candidate choice process, from the hESC transcriptome to the final list of 92 proteins. 


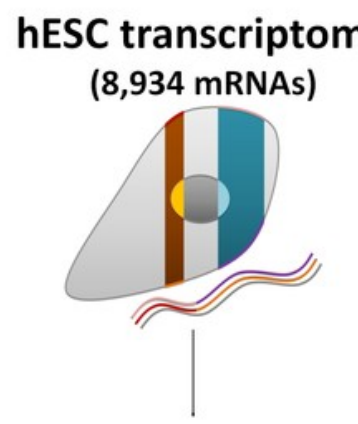

hESC-EC+TF transcriptome (1,469 mRNAs)

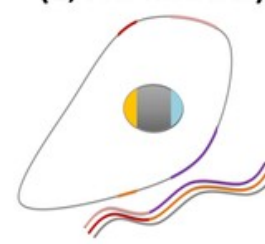

ESC transcriptome

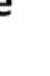

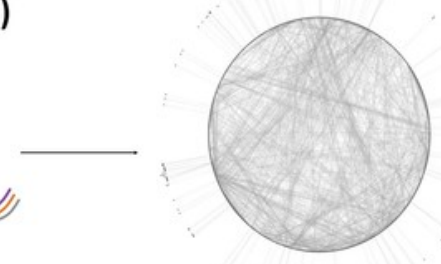

hESC-EC+TF interactome (702 proteins)

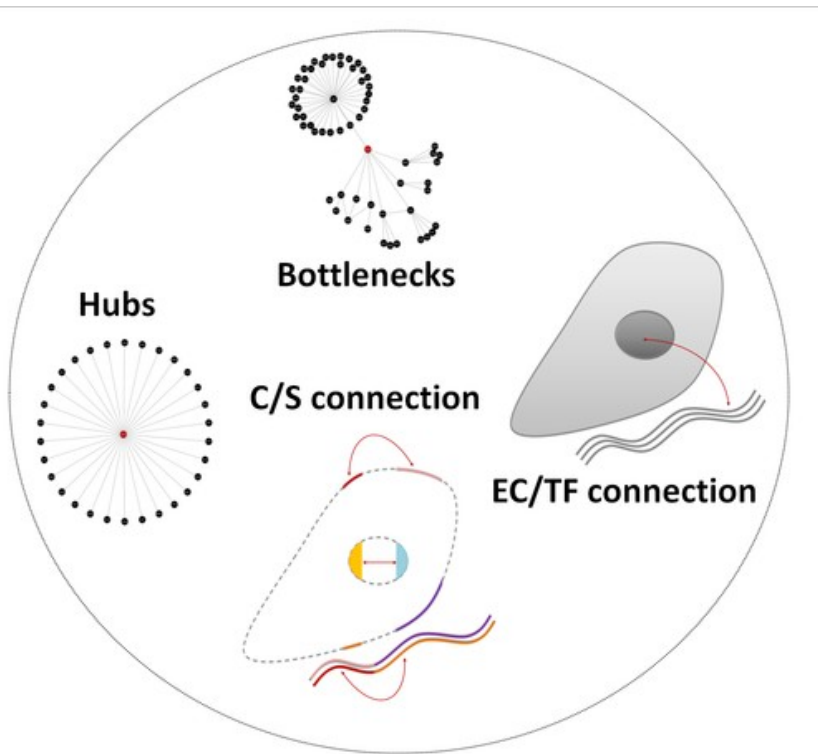

hESC-EC+TF Candidate list

(ALL_EC+TF = 387 proteins)

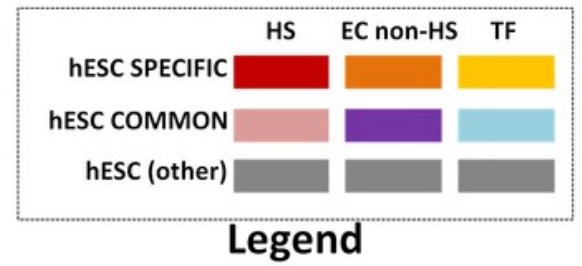

\section{Common/Specific hESC-EC+TF hESC-EC Candidate list}

Candidate list

(ALL_EC $=188$ proteins)

(C+S_EC+TF $=155$ proteins)
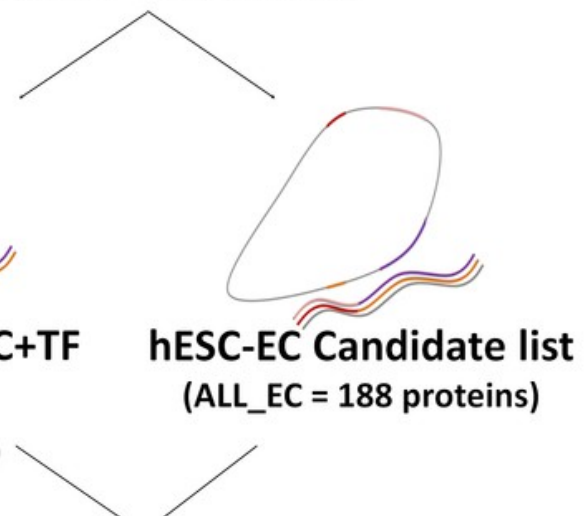

Common/Specific hESC-EC

Candidate list

(C+S_EC $=92$ proteins) 


\section{Figure 3}

Overlaps of transcriptomes and sub-transcriptomes

A) Main overlaps of hESC and hESC-derived cell transcriptomes. Grey: hESC transcriptome; Blue: endothelial cell transcriptome; Red: fibroblast transcriptome; Green: mixture of hESCderived cell transcriptome. B) The overlaps of hESC sub-transcriptomes. The hESC transcriptome is composed of 8,934 mRNAs in total with a hESC-specific part (1,010 mRNAs, brown part), a common part (1,933 mRNAs, blue part) shared with the hESC-derived cells, and the rest of the mRNAs (grey). Sub-transcriptomes can be highlighted: the HS binding proteins part (191 mRNAs, specific in red and common in pink); the extracellular part (EC) without HS binding proteins (576 mRNAs, specific in orange and common in purple); the transcription factor related part (TF, 721 mRNAs, specific in yellow and common in light blue).

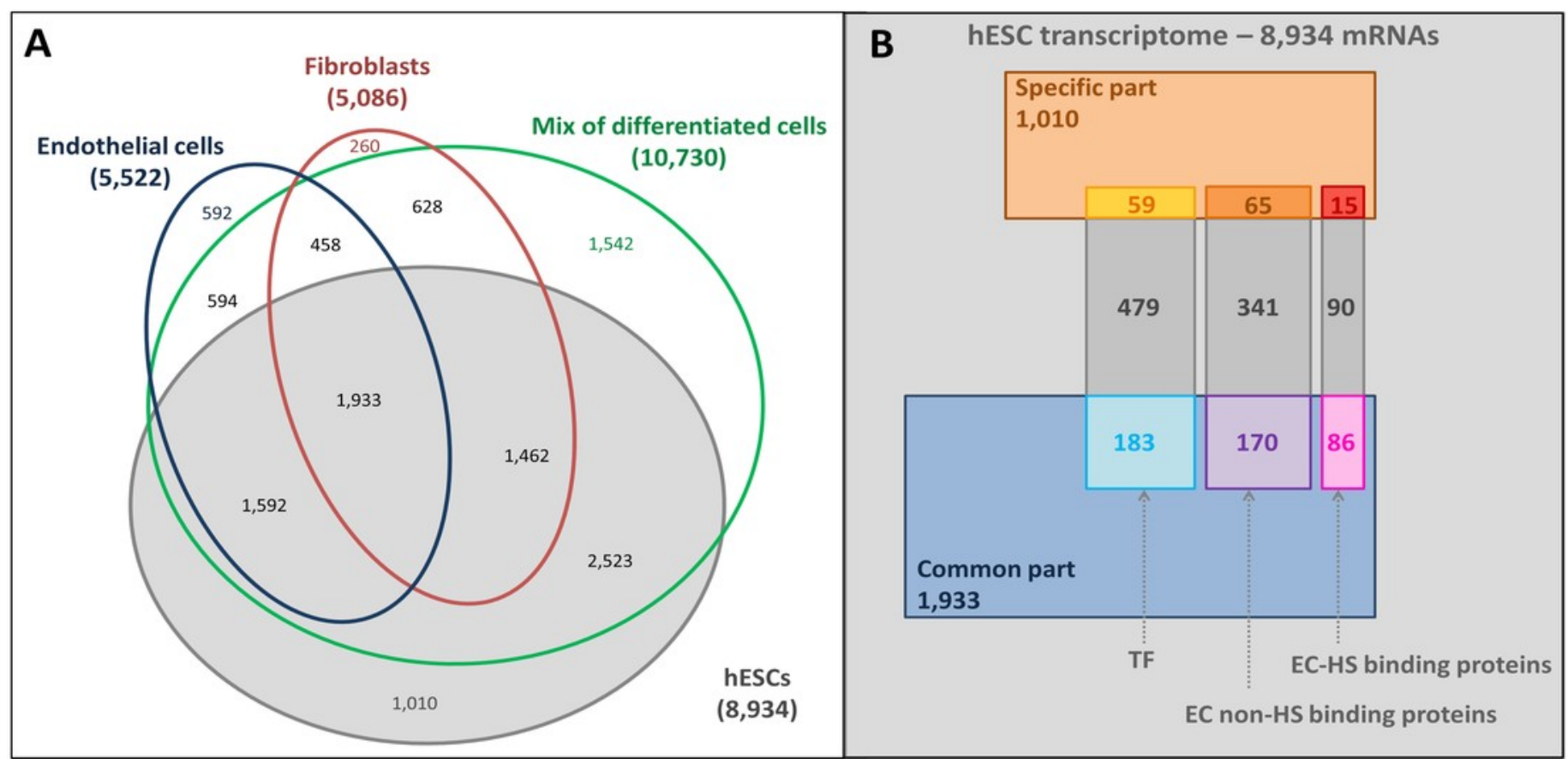




\section{Figure 4}

Figure 4 - General network parameters of EC+TF putative interactomes

A) The average clustering coefficient of real networks and their corresponding average randomised networks with SEM bars (One sample t-test, $n=5, p$-value $<0.001$ ). B) The node degree distribution $\mathrm{P}(\mathrm{k})$ and $\mathrm{C}$ ) the clustering coefficient distribution $\mathrm{C}(\mathrm{k})(\mathrm{C}$ : common part; $\mathrm{S}$ : specific part; R: random; EC: extracellular part; TF: transcription factor related part).

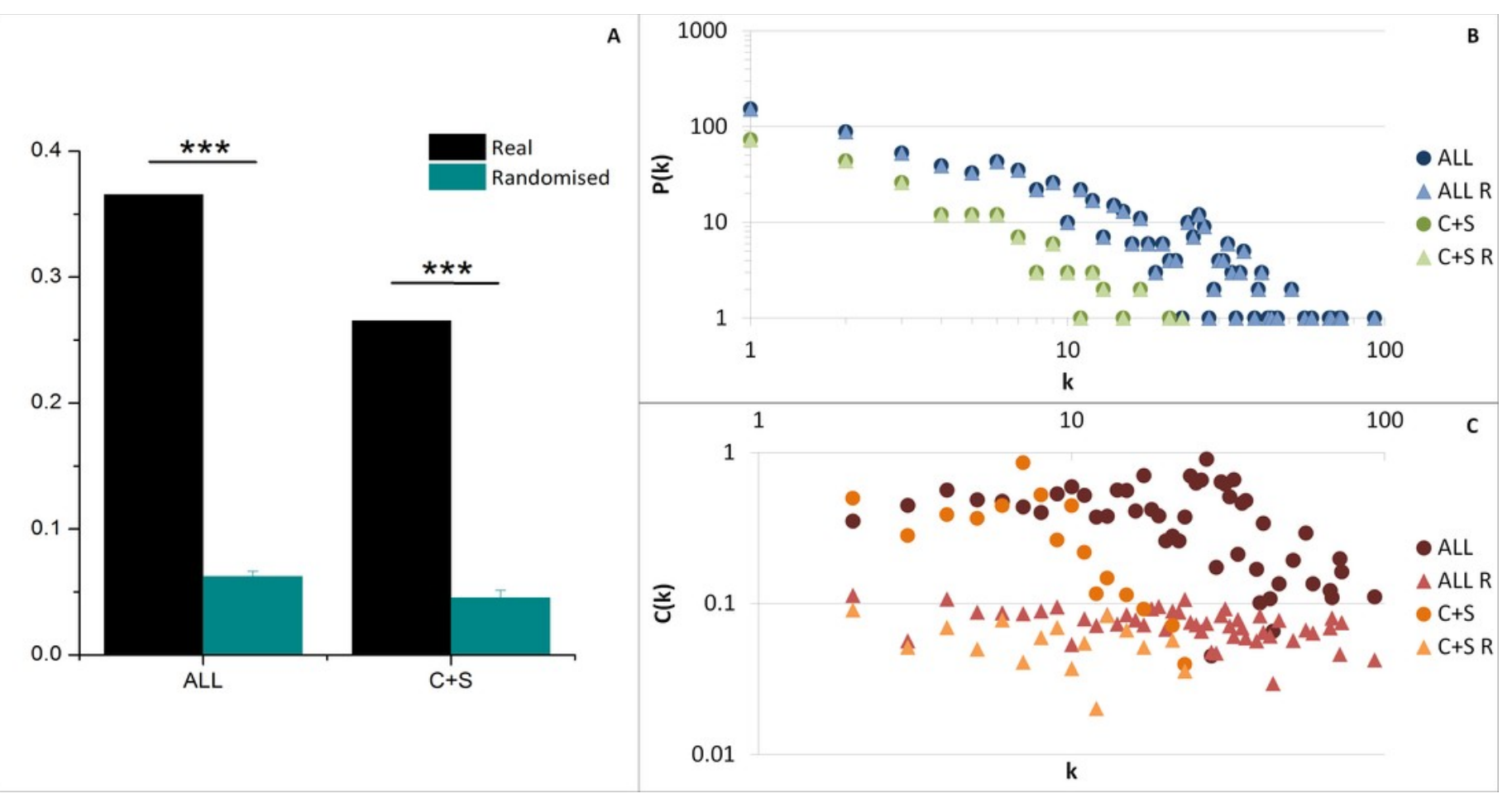




\section{Figure 5}

$\mathrm{GO} / \mathrm{KEGG}$ analyses of $\mathrm{EC}+\mathrm{TF}$ putative interactomes

A) GO Biological Processes term enrichment (against Homo sapiens), in fold change. B) Percentage of the total number of proteins in Homo sapiens related to GO Biological

Processes that are present in $\mathrm{ALL}$ and $\mathrm{C}+\mathrm{S}$ putative interactomes (C: common part; S: specific part). 


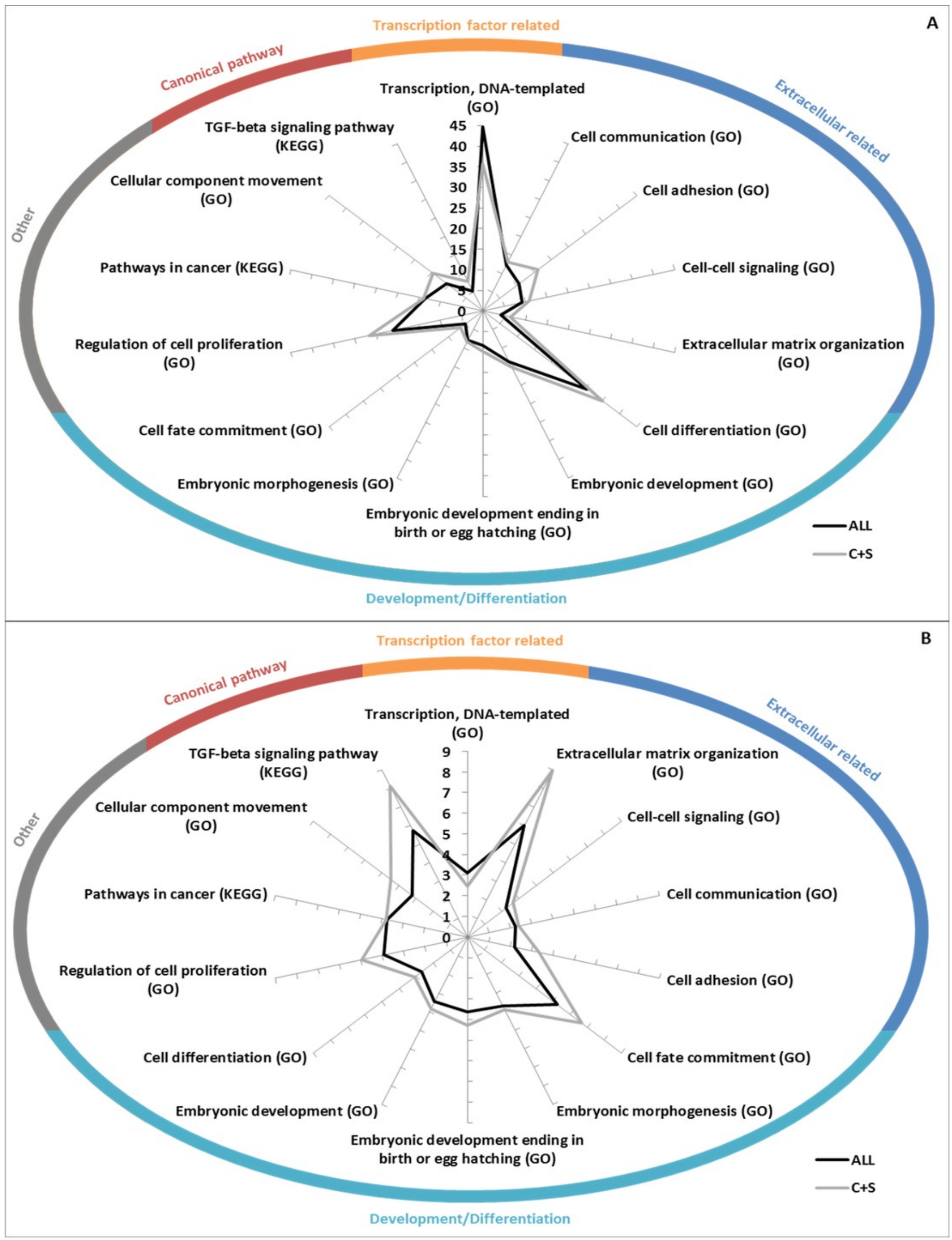




\section{Figure 6}

Comparative enrichment trends within the candidate protein list

A) Enrichments in specific, common and other parts with HS, EC non-HS and TF. B)

Enrichments in HS, EC non-HS and TF parts with EC/TF interface, C/S interface, hubs and bottlenecks (C: common part; S: specific part; EC: extracellular part; HS: heparan sulfate binding proteins; TF: transcription factor related part).

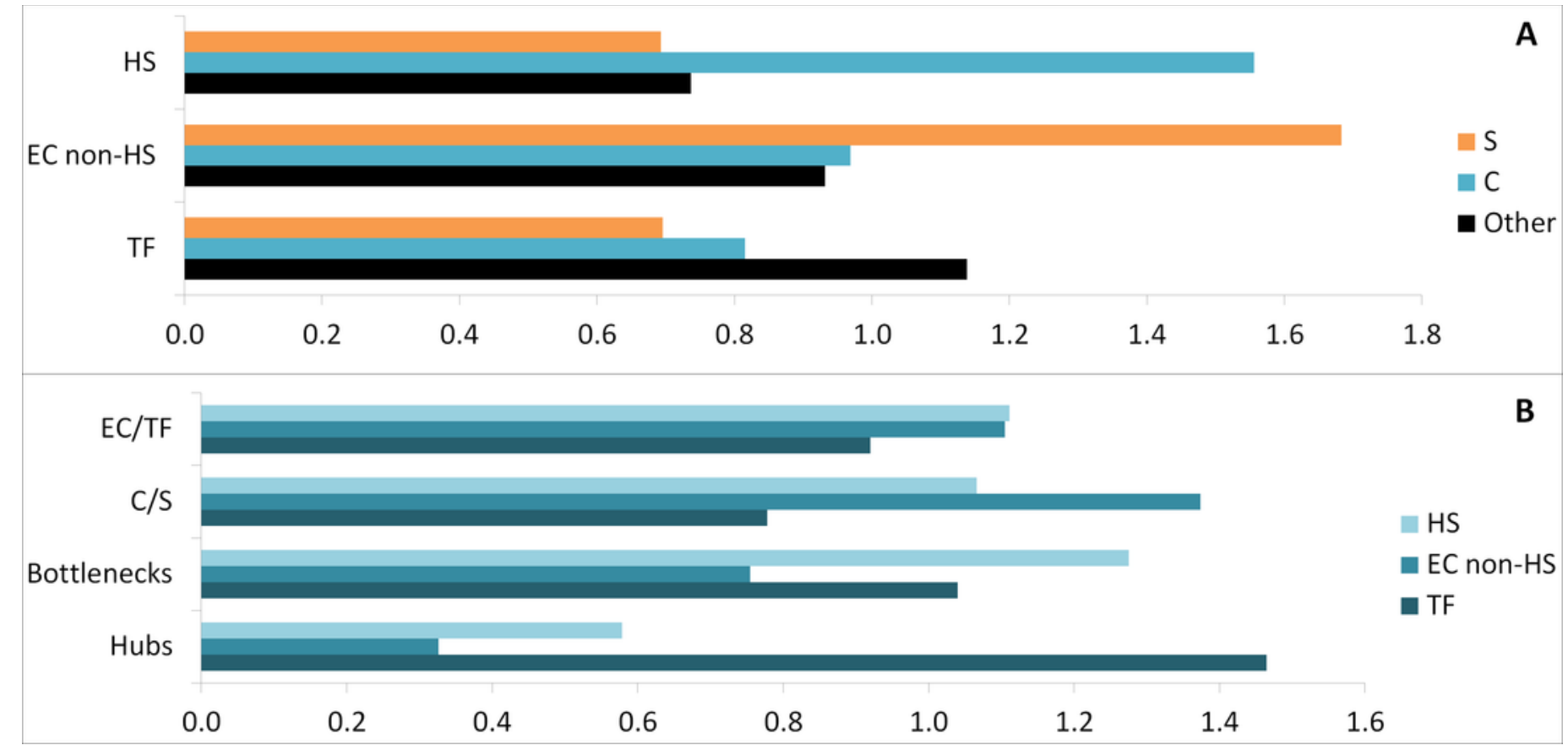




\section{Table 1 (on next page)}

Microarray datasets analysis

The access number (second column) gives access to the dataset in ArrayExpress database. Cell types and cell lines (first column), main cell culture conditions (third column), publications linked to the dataset (when available, fourth column) and the number of microarrays used per analysis (fifth column) are specified. Expressed gene lists for each algorithm (RMA, GC-RMA and MAS5.0) as the total and intersection lists are presented. Four hESC datasets (E-GEOD6561, -15148, -18265 and -26672) have been used to build mix1. Six hESC-derived cell datasets (E-GEOD-9196, -9832, -9940, -14897, -19735 and -21668) have been used to build mix2. Datasets in bold represent the final transcriptomes used for further analysis: mix1 for hESCs, E-GEOD-9832 for the fibroblasts, E-GEOD-19735 for the endothelial cells and mix2 for the mixture of hESC-derived cells (MEFs mouse embryonic fibroblasts; HFFs human foreskin fibroblasts; SR serum replacer). 


\section{PeerJ Reviewing Manuscript}

\begin{tabular}{|c|c|c|c|c|c|c|c|c|c|}
\hline $\begin{array}{l}\text { Cell type } \\
\text { (Cell line) }\end{array}$ & $\begin{array}{c}\text { Access } \\
\text { Numb } \\
\text { er }\end{array}$ & $\begin{array}{c}\text { Linked } \\
\text { publicati } \\
\text { on }\end{array}$ & $\begin{array}{c}\text { Main cell } \\
\text { culture } \\
\text { feature }\end{array}$ & $\begin{array}{c}\text { Number } \\
\text { of } \\
\text { microarra } \\
\text { ys }\end{array}$ & RMA & $\begin{array}{l}\text { GC- } \\
\text { RMA }\end{array}$ & $\begin{array}{c}\text { MAS5. } \\
0\end{array}$ & $\underset{L}{\text { TOTA }}$ & $\begin{array}{c}\text { INTERSECTI } \\
\text { ON }\end{array}$ \\
\hline $\begin{array}{r}\text { hESCs } \\
(\mathrm{H} 14)\end{array}$ & $\begin{array}{c}\text { E- } \\
\text { GEOD- } \\
6561\end{array}$ & $\begin{array}{l}\text { (Baker et } \\
\text { al. 2007) }\end{array}$ & $\begin{array}{l}\text { On feeder cells } \\
\text { (irradiated } \\
\text { MEFs) } \\
\text { FGF2 (4 ng/mL) } \\
20 \% \text { KnockOut } \\
\text { SR }\end{array}$ & 4 & 9672 & 8680 & 9822 & $\begin{array}{c}1193 \\
0\end{array}$ & 7088 \\
\hline $\begin{array}{c}\text { hESCS } \\
(\mathrm{H} 1, \mathrm{H} 7, \mathrm{H} 9 \\
\mathrm{H} 13, \mathrm{H} 14)\end{array}$ & $\begin{array}{c}\text { E- } \\
\text { GEOD- } \\
15148\end{array}$ & $\frac{\text { (Yu et al. }}{\underline{2009})}$ & $\begin{array}{l}\text { On feeder cells } \\
\text { (irradiated } \\
\text { MEFs) } \\
\text { FGF2 (100 } \\
\text { ng/mL) } \\
20 \% \text { KnockOut } \\
\text { SR } \\
\text { OR } \\
\text { On feeder-free } \\
\text { matrigel } \\
\text { Conditioned } \\
\text { medium }\end{array}$ & 10 & 8798 & 10554 & 10293 & $\begin{array}{c}1246 \\
7\end{array}$ & 7395 \\
\hline hESCs & $\begin{array}{c}\text { E- } \\
\text { GEOD- } \\
18265\end{array}$ & I & $\begin{array}{c}\text { On feeder cells } \\
\text { (inactivated } \\
\text { HFFs) } \\
\text { FGF2 (10 ng/mL) } \\
20 \% \text { KnockOut } \\
\text { SR }\end{array}$ & 5 & 9602 & 11325 & 10966 & $\begin{array}{c}1349 \\
9\end{array}$ & 7791 \\
\hline $\begin{array}{c}\text { hESCS } \\
(\mathrm{H} 1)\end{array}$ & $\begin{array}{c}\text { E- } \\
\text { GEOD- } \\
26672\end{array}$ & $\frac{(\mathrm{Hu} \text { et al. }}{\underline{2011})}$ & $\begin{array}{l}\text { On feeder cells } \\
\text { (irradiated } \\
\text { MEFs) } \\
\text { FGF2 (4 ng/mL) } \\
20 \% \text { KnockOut } \\
\text { SR }\end{array}$ & 5 & 9656 & 11285 & 10843 & $\begin{array}{c}1279 \\
0\end{array}$ & 8235 \\
\hline hESCs & Mix1 & I & & 24 & $\begin{array}{c}1100 \\
1\end{array}$ & $\begin{array}{c}1217 \\
3\end{array}$ & 11546 & $\begin{array}{c}1404 \\
3\end{array}$ & 8934 \\
\hline $\begin{array}{c}\text { Embryoid } \\
\text { bodies }\end{array}$ & \multirow{2}{*}{$\begin{array}{c}\text { E- } \\
\text { GEOD- } \\
9196 \\
\end{array}$} & \multirow{2}{*}{$\frac{(\text { Lu et al. }}{\underline{2007})}$} & & 9 & 5142 & 6308 & 6667 & 8935 & 3576 \\
\hline Blast cells & & & & 9 & 4142 & 5866 & 6731 & 8617 & 3175 \\
\hline Fibroblasts & $\begin{array}{c}\text { E- } \\
\text { GEOD- } \\
9832 \\
\end{array}$ & $\begin{array}{c}\text { (Park et } \\
\text { al. 2008) }\end{array}$ & & 3 & 6471 & 7510 & 8072 & 9795 & 5086 \\
\hline $\begin{array}{c}\text { Neural } \\
\text { progenitors }\end{array}$ & \multirow{2}{*}{$\begin{array}{c}\text { E- } \\
\text { GEOD- } \\
9940\end{array}$} & \multirow[t]{2}{*}{ I } & & 12 & 6939 & 8432 & 7309 & $\begin{array}{c}1151 \\
7\end{array}$ & 3944 \\
\hline $\begin{array}{l}\text { Embryoid } \\
\text { bodies }\end{array}$ & & & & 3 & 1356 & 2485 & 5009 & 5812 & 942 \\
\hline Hepatic cells & $\begin{array}{l}\text { E- } \\
\text { GEOD- } \\
14897\end{array}$ & $\frac{(\text { Si-Tayeb }}{\underline{\text { et al. }}}$ & & 3 & 1669 & 2659 & 4017 & 4864 & 1299 \\
\hline $\begin{array}{c}\text { Endothelial } \\
\text { cells }\end{array}$ & \multirow{2}{*}{$\begin{array}{l}\text { E- } \\
\text { GEOD- } \\
19735\end{array}$} & \multirow[t]{2}{*}{. } & & 4 & 7166 & 9237 & 8448 & $\begin{array}{c}1108 \\
5\end{array}$ & 5522 \\
\hline $\begin{array}{l}\text { Embryoid } \\
\text { bodies }\end{array}$ & & & & 2 & 704 & 1832 & 1156 & 2079 & 583 \\
\hline $\begin{array}{l}\text { Mesenchema } \\
\text { I progenitors }\end{array}$ & $\begin{array}{l}\text { E- } \\
\text { GEOD- } \\
21668\end{array}$ & $\frac{\text { Evseenko }}{\frac{\text { et al. }}{2010}}$ & & 3 & 861 & 1482 & 2543 & 3087 & 638 \\
\hline $\begin{array}{l}\text { Differentiat } \\
\text { ed cells }\end{array}$ & Mix2 & I & & 48 & $\begin{array}{c}1617 \\
4\end{array}$ & $\begin{array}{c}1417 \\
2\end{array}$ & 12134 & $\begin{array}{c}1745 \\
8\end{array}$ & 10730 \\
\hline
\end{tabular}




\section{Table 2 (on next page)}

Transcriptomes and literature comparisons, a selection of markers

'Transcriptome' column: transcriptome(s) or sub-transcriptome containing the mRNAs (Endo: endothelial cell; F: fibroblast; Mix: mixture of hESC-derived cells). GO term column: GO terms found during the GO extraction (CA: cell adhesion; $\mathrm{CC}$ : cell cycle; $\mathrm{CCo}$ : cell communication; CS: cytoskeleton organisation; J: cell junction; EC: extracellular part; HS: heparan sulfate binding proteins; TF: transcription factor related part). A) Signalling molecules required for pluripotency/self-renewal; B) Germ layer markers and C) Molecules related to culture medium of hESCs. 
PeerJ Reviewing Manuscript

\begin{tabular}{|c|c|c|c|c|c|}
\hline & $\begin{array}{c}\text { Marker/Fa } \\
\text { mily }\end{array}$ & $\begin{array}{c}\text { Acrony } \\
\text { m }\end{array}$ & Name & $\begin{array}{c}\text { Transcriptom } \\
\text { e }\end{array}$ & GO term \\
\hline $\mathbf{A}$ & $\begin{array}{l}\text { Embryonic } \\
\text { stem cell }\end{array}$ & $\begin{array}{l}\text { PTEN } \\
\text { TERT } \\
\text { GDF3 } \\
\text { NODAL } \\
\text { ZIC3 } \\
\text { SOX2 } \\
\text { POU5F1 }\end{array}$ & $\begin{array}{l}\text { phosphatase and tensin homolog } \\
\text { telomerase reverse transcriptase } \\
\text { growth differentiation factor } 3 \\
\text { nodal homolog (mouse) } \\
\text { Zic family member } 3 \\
\text { SRY (sex determining region Y)-box } 2 \\
\text { POU class } 5 \text { homeobox } 1\end{array}$ & $\begin{array}{l}\text { hESC } \\
\text { (COMMON) } \\
\text { hESC } \\
\text { (SPECIFIC) } \\
\text { hESC } \\
\text { (SPECIFIC) } \\
\text { hESC } \\
\text { (SPECIFIC) } \\
\text { hESC, Mix } \\
\text { hESC, Mix } \\
\text { hESC, Mix }\end{array}$ & $\begin{array}{c}\text { EC non-HS } \\
\text { CCo/EC non-HS } \\
\text { TF } \\
\text { CC/CCo/TF } \\
\text { CCo/TF }\end{array}$ \\
\hline \multirow{3}{*}{ B } & Ectoderm & $\begin{array}{l}\text { NEFH } \\
\text { TUBB3 }\end{array}$ & $\begin{array}{l}\text { neurofilament, heavy polypeptide } \\
\text { tubulin, beta } 3 \text { class III }\end{array}$ & $\begin{array}{c}\text { hESC } \\
\text { (COMMON) } \\
\text { hESC, Mix } \\
\end{array}$ & $\begin{array}{l}\mathrm{CS} \\
\mathrm{CCo} \\
\end{array}$ \\
\hline & Endoderm & $\begin{array}{l}\text { KRT19 } \\
\text { SOX7 }\end{array}$ & $\begin{array}{l}\text { keratin } 19 \\
\text { SRY (sex determining region Y)-box } 7\end{array}$ & $\begin{array}{c}\text { hESC } \\
\text { (COMMON) } \\
\text { hESC, Endo, } \\
\text { Mix }\end{array}$ & $\begin{array}{c}\mathrm{CS} \\
\mathrm{CCO} / \mathrm{TF}\end{array}$ \\
\hline & Mesoderm & $\begin{array}{l}\text { KDR } \\
\text { PDGFRA } \\
\text { VIM }\end{array}$ & $\begin{array}{l}\text { kinase insert domain receptor (a type III } \\
\text { receptor tyrosine kinase) (VEGFR) } \\
\text { platelet-derived growth factor receptor, alpha } \\
\text { polypeptide } \\
\text { Vimentin }\end{array}$ & $\begin{array}{l}\text { hESC, Mix } \\
\text { hESC } \\
\text { (COMMON) } \\
\text { hESC } \\
\text { (COMMON) }\end{array}$ & $\begin{array}{c}\text { CA/CCo/HS } \\
\text { CS/CA/CCo } \\
\text { CS }\end{array}$ \\
\hline \multirow{3}{*}{ C } & $\begin{array}{c}\text { Fibronecti } \\
n\end{array}$ & $\begin{array}{l}\text { FN1 } \\
\text { ITGA5 } \\
\text { ITGB1 }\end{array}$ & $\begin{array}{l}\text { fibronectin } 1 \\
\text { integrin, alpha } 5 \text { (fibronectin receptor, alpha } \\
\text { polypeptide) } \\
\text { integrin, beta } 1 \text { (fibronectin receptor, beta } \\
\text { polypeptide, antigen CD29 includes MDF2, } \\
\text { MSK12) }\end{array}$ & $\begin{array}{l}\text { hESC } \\
\text { (COMMON) } \\
\text { hESC, Mix } \\
\text { hESC, Endo, } \\
\text { Mix }\end{array}$ & $\begin{array}{l}\mathrm{CA} / \mathrm{HS} \\
\mathrm{CA} / \mathrm{CCO} / \mathrm{J} / \mathrm{HS} \\
\mathrm{CS} / \mathrm{CA} / \mathrm{CC} / \mathrm{CCO} / \mathrm{J} / \\
\mathrm{HS}\end{array}$ \\
\hline & $\begin{array}{l}\text { Fibroblast } \\
\text { Growth } \\
\text { Factor }\end{array}$ & $\begin{array}{l}\text { FGF2 } \\
\text { FGFR1 } \\
\text { FGFR2 } \\
\text { FGFR3 } \\
\text { FGFR4 }\end{array}$ & $\begin{array}{l}\text { Fibroblast growth factor } 2 \\
\text { Fibroblast growth factor receptor } 1 \\
\text { Fibroblast growth factor receptor } 2 \\
\text { fibroblast growth factor receptor } 3 \\
\text { Fibroblast growth factor receptor } 4\end{array}$ & $\begin{array}{c}\text { hESC } \\
\text { (COMMON) } \\
\text { hESC } \\
\text { (COMMON) } \\
\text { hESC, Endo, } \\
\text { Mix } \\
\text { hESC, Endo, } \\
\text { Mix } \\
\text { hESC } \\
\text { (SPECIFIC) }\end{array}$ & $\begin{array}{l}\mathrm{CC} / \mathrm{CCO} / \mathrm{HS} / \mathrm{TF} \\
\mathrm{CC} / \mathrm{CCO} / \mathrm{HS} \\
\mathrm{CC} / \mathrm{CCO} / \mathrm{HS} \\
\mathrm{CCo} / \mathrm{J} / \mathrm{HS} \\
\mathrm{CCo} / \mathrm{J} / \mathrm{HS}\end{array}$ \\
\hline & Activin A & $\begin{array}{l}\text { ACVR1B } \\
\text { ACVR1C } \\
\text { ACVR2A } \\
\text { ACVR2B } \\
\text { INHBA }\end{array}$ & $\begin{array}{l}\text { activin A receptor, type IB (ALK4) } \\
\text { activin A receptor, type IC } \\
\text { activin A receptor, type IIA } \\
\text { activin A receptor, type IIB } \\
\text { inhibin, beta A / Activin A }\end{array}$ & $\begin{array}{c}\text { hESC } \\
\text { (COMMON) } \\
\text { hESC } \\
\text { (SPECIFIC) } \\
\text { hESC, F, Mix } \\
\text { hESC, Endo, } \\
\text { Mix } \\
\text { hESC } \\
\text { (COMMON) } \\
\end{array}$ & $\begin{array}{c}\mathrm{CC} / \mathrm{CCO} / \mathrm{EC} \text { non- } \\
\mathrm{HS} \\
\mathrm{CCO} \\
\mathrm{CCO} \\
\mathrm{CCO} / \mathrm{EC} \text { non-HS } \\
\mathrm{CC} / \mathrm{CCO} / \mathrm{HS}\end{array}$ \\
\hline
\end{tabular}




\section{Table 3 (on next page)}

The list of candidates, an overview

The 'hubs' column gives the degree; the 'bottlenecks' column gives the betweenness; the 'S/C' column indicates if the protein is in the specific/common interface; the 'EC/TF' column indicates if the protein is in the EC/TF interface; the 'KEGG pathway' column indicates the number of pathway involving each protein (GO: Gene Onlotogy; KEGG: Kyoto Encyclopedia of Genes and Genomes; C: common part; S: specific part; EC: extracellular part; TF: transcription factor related part; J: cell junction). (see Table S4 for a complete list). 


\section{PeerJ Reviewing Manuscript}

\begin{tabular}{|c|c|c|c|c|c|c|c|c|}
\hline & $\begin{array}{c}\text { Acron } \\
\text { ym }\end{array}$ & Name & GO term & $\begin{array}{l}\text { Hu } \\
\text { bs }\end{array}$ & $\begin{array}{c}\text { Bottlene } \\
\text { cks }\end{array}$ & $\begin{array}{l}\text { S/ } \\
\text { C }\end{array}$ & $\begin{array}{l}\text { EC/ } \\
\text { TF }\end{array}$ & $\begin{array}{c}\text { KEGG } \\
\text { pathw } \\
\text { ay }\end{array}$ \\
\hline \multirow{21}{*}{ C } & ACTN4 & actinin, alpha 4 & EC non-HS/CS & 17 & & & & 4 \\
\hline & $\begin{array}{c}\text { ACVR1 } \\
\text { B }\end{array}$ & activin A receptor, type IB (ALK4) & $\begin{array}{l}\text { EC non- } \\
\mathrm{HS} / \mathrm{CC} / \mathrm{CCo}\end{array}$ & & & $\mathrm{X}$ & $X$ & 1 \\
\hline & ADM & adrenomedullin & EC non-HS/CCo & & 4050.8 & $\mathrm{X}$ & $X$ & 0 \\
\hline & BMP2 & bone morphogenetic protein 2 & HS/CC/CCo & & 2693.9 & $\mathrm{X}$ & $\mathrm{X}$ & 3 \\
\hline & DMD & dystrophin & $\begin{array}{l}\text { EC non- } \\
\mathrm{HS} / \mathrm{CS} / \mathrm{CCO}\end{array}$ & & & $x$ & & 0 \\
\hline & FGFR1 & Fibroblast growth factor receptor 1 & $\mathrm{HS} / \mathrm{CC} / \mathrm{CCO}$ & & 2634.2 & $X$ & $X$ & 5 \\
\hline & FN1 & fibronectin 1 & $\mathrm{HS} / \mathrm{CA}$ & 26 & 6988.8 & & $\mathrm{X}$ & 5 \\
\hline & IL6 & Interleukin 6 & $\mathrm{HS} / \mathrm{CCO}$ & & & & $x$ & 4 \\
\hline & INHBA & inhibin, beta A / Activin A & $\mathrm{HS} / \mathrm{CC} / \mathrm{CCO}$ & & & $\mathrm{X}$ & & 2 \\
\hline & ITGA6 & integrin, alpha 6 (CD49f) & $\begin{array}{c}\text { EC non- } \\
\mathrm{HS} / \mathrm{CA} / \mathrm{CCO} / \mathrm{J}\end{array}$ & 40 & 15218.1 & & $X$ & 6 \\
\hline & ITGAV & $\begin{array}{l}\text { integrin, alpha } \mathrm{V} \text { (vitronectin } \\
\text { receptor) }\end{array}$ & $\mathrm{HS} / \mathrm{CA} / \mathrm{CCO}$ & 40 & 12409.4 & & $x$ & 6 \\
\hline & JAM3 & junctional adhesion molecule 3 & $\begin{array}{l}\text { EC non- } \\
\mathrm{HS} / \mathrm{CA} / \mathrm{CCo} / \mathrm{J}\end{array}$ & & & $\mathrm{X}$ & $x$ & 2 \\
\hline & LAMA1 & laminin, alpha 1 & $\mathrm{HS} / \mathrm{CA} / \mathrm{CCO}$ & 15 & & & $\mathrm{X}$ & 4 \\
\hline & MET & (hepatocyte growth factor receptor & $\mathrm{HS} / \mathrm{CS} / \mathrm{CC} / \mathrm{CCO}$ & 24 & 10501.7 & $\mathrm{X}$ & $\mathrm{X}$ & 6 \\
\hline & PLAT & plasminogen activator, tissue & $\mathrm{HS} / \mathrm{CCO}$ & & 2552.8 & & $\mathrm{X}$ & 0 \\
\hline & PLAU & plasminogen activator, urokinase & $\mathrm{HS} / \mathrm{CA} / \mathrm{CCO}$ & & & & $x$ & 1 \\
\hline & $\begin{array}{l}\text { SERPIN } \\
\text { E1 }\end{array}$ & $\begin{array}{l}\text { serpin peptidase inhibitor, clade } \mathrm{E} \text {, } \\
\text { member } 1\end{array}$ & $\mathrm{HS} / \mathrm{CA} / \mathrm{CCO}$ & 24 & 10022.8 & & $x$ & 1 \\
\hline & $\begin{array}{l}\text { SERPIN } \\
\quad \text { II }\end{array}$ & $\begin{array}{l}\text { serpin peptidase inhibitor, clade I, } \\
\text { member } 1\end{array}$ & EC non-HS/CA & & & & $\mathrm{X}$ & 0 \\
\hline & TGFB2 & transforming growth factor, beta 2 & $\mathrm{HS} / \mathrm{CA} / \mathrm{CC} / \mathrm{CCO}$ & 25 & 10580.8 & $\mathrm{X}$ & $X$ & 6 \\
\hline & THBS1 & thrombospondin 1 & $\mathrm{HS} / \mathrm{CA} / \mathrm{CC} / \mathrm{CCO}$ & & 2066.0 & & $\mathrm{X}$ & 5 \\
\hline & VEGFA & vascular endothelial growth factor A & $\mathrm{HS} / \mathrm{CA} / \mathrm{CCO}$ & 16 & 6817.1 & & $\mathrm{X}$ & 6 \\
\hline \multirow{9}{*}{$\mathbf{S}$} & $\mathrm{CDH} 8$ & cadherin 8, type 2 & $\mathrm{HS} / \mathrm{CA}$ & & & $\mathrm{X}$ & $\mathrm{X}$ & 0 \\
\hline & FGF4 & fibroblast growth factor 4 & $\mathrm{HS} / \mathrm{CA} / \mathrm{CCO}$ & & & $\mathrm{X}$ & $\mathrm{X}$ & 3 \\
\hline & FGFR4 & Fibroblast growth factor receptor 4 & $\mathrm{HS} / \mathrm{CCO}$ & & & $\mathrm{X}$ & $\mathrm{X}$ & 4 \\
\hline & IDE & insulin-degrading enzyme & EC non-HS/CCo & & & $\mathrm{X}$ & & 0 \\
\hline & INHBE & inhibin, beta $\mathrm{E}$ & EC non-HS & & & $\mathrm{X}$ & & 2 \\
\hline & NODAL & nodal homolog (mouse) & EC non-HS/CCo & & & $x$ & & 1 \\
\hline & $\begin{array}{l}\text { PLXNB } \\
1\end{array}$ & plexin B1 & EC non-HS/CCo & & & $x$ & & 0 \\
\hline & TTN & titin & EC non-HS/CS/CC & & & $\mathrm{x}$ & $\mathrm{X}$ & 0 \\
\hline & WIF1 & WNT inhibitory factor 1 & EC non-HS/CCo & & & $\mathrm{X}$ & $\mathrm{X}$ & 1 \\
\hline
\end{tabular}

